OPEN ACCESS

Edited by:

Sergio Rossi,

Université du Québec à Chicoutimi,

Canada

Reviewed by:

Shaokang Zhang,

Chinese Academy of Sciences, China

Laura Fernández-de-Uña,

INRA Centres Nancy-Lorraine, France

*Correspondence:

Gerhard Wieser

gerhard.wieser@uibk.ac.at

Specialty section:

This article was submitted to

Functional Plant Ecology,

a section of the journal

Frontiers in Plant Science

Received: 28 February 2018

Accepted: 11 May 2018

Published: 29 May 2018

Citation

Gruber A, Oberhuber W and Wieser G (2018) Nitrogen Addition and Understory Removal but Not Soil

Warming Increased Radial Growth of Pinus cembra at Treeline in the Central Austrian Alps.

Front. Plant Sci. 9:711. doi: 10.3389/fpls.2018.00711

\section{Nitrogen Addition and Understory Removal but Not Soil Warming Increased Radial Growth of Pinus cembra at Treeline in the Central Austrian Alps}

\author{
Andreas Gruber ${ }^{1,2}$, Walter Oberhuber ${ }^{1}$ and Gerhard Wieser ${ }^{3 *}$ \\ ${ }^{1}$ Department of Botany, University of Innsbruck, Innsbruck, Austria, ${ }^{2}$ Naturwerkstatt Tirol, itworks Personalservice \& \\ Beratung gemeinnützige GmbH, Zams, Austria, ${ }^{3}$ Department of Alpine Timberline Ecophysiology, Federal Research and \\ Training Centre for Forests, Natural Hazards and Landscape (BFW), Innsbruck, Austria
}

Beside low temperatures, limited tree growth at the alpine treeline may also be attributed to a lack of available soil nutrients and competition with understory vegetation. Although intra-annual stem growth of Pinus cembra has been studied intensively at the alpine treeline, the responses of radial growth to soil warming, soil fertilization, and below ground competition awaits clarification. In this study we quantified the effects of nitrogen (N) fertilization, soil warming, and understory removal on stem radial growth of $P$. cembra at treeline. Soil warming was achieved by roofing the forest floor with a transparent polyvinyl skin, while understory competition was prevented by shading the forest floor with a non-transparent foil around six trees each. Six trees received $\mathrm{N}$ - fertilization and six other trees served as controls. Stem growth was monitored with band dendrometers during the growing seasons 2012-2014. Our 3 years experiment showed that soil warming had no considerable effect on radial growth. Though understory removal through shading was accompanied by root-zone cooling, understory removal as well as $\mathrm{N}$ fertilization led to a significant increase in radial growth. Hardly affected was tree root biomass, while $\mathrm{N}$-fertilization and understory removal significantly increased in 100-needle surface area and 100-needle dry mass, implying a higher amount of $\mathrm{N}$ stored in needles. Overall, our results demonstrate that beside low temperatures, tree growth at cold-climate boundaries may also be limited by root competition for nutrients between trees and understory vegetation. We conclude that tree understory interactions may also control treeline dynamics in a future changing environment.

Keywords: alpine treeline, Pinus cembra, intra- annual stem growth, soil warming, nitrogen fertilization, understory removal, competition

\section{INTRODUCTION}

Although the alpine treeline has attracted the interest of researchers for more than one century (Brockmann-Jerosch, 1919; Däniker, 1923; Wardle, 1974; Tranquillini, 1979; Körner, 1998, 2012; Holtmeier, 2003; Wieser and Tausz, 2007; Piper et al., 2016), the causes to treeline formation are still under debate. Nevertheless, it has been hypothesized that low temperatures limit growth processes 
in meristematic tissues (growth limitation hypothesis; Körner, 1998, 2012; Hoch and Körner, 2003). A world-wide survey across natural high elevation treelines indicates that growing season mean root-zone temperature constrains tree growth in temperature limited ecosystems (Sveinbjörnsson, 2000; Körner and Hoch, 2006). In a global survey, Körner and Paulsen (2004) found that a growing season mean soil temperature of $6.4 \pm 0.7^{\circ} \mathrm{C}$ in $10 \mathrm{~cm}$ soil depths matches the upper elevational limit of tree growth. Moreover, a growth decline at the alpine treeline may also be attributed to a lack of available soil nutrients (Tranquillini, 1979; Sveinbjörnsson et al., 1992), especially nitrogen (Hoch, 2013) and competition with understory vegetation (Elliott, 2011; Grau et al., 2012; Liang et al., 2016).

Given that alpine treelines are strongly temperature limited, they are considered to be sensitive to climate warming (Walther et al., 2005; Holtmeier and Broll, 2007; Wieser et al., 2009; Liang et al., 2016; Camarero et al., 2017). So far, only a few studies evaluated the effect of soil warming on tree growth in boreal forests (Strömgren and Linder, 2002; Dao et al., 2015) and at treeline in the Swiss (Dawes et al., 2015) and French Alps (Loranger et al., 2016) with results ranging from a strong growth stimulation to no stimulation in growth. In a pilot study at treeline in the Austrian Alps, Gruber et al. (2010) investigated the effect of root-zone warming and cooling on radial growth of Pinus cembra. Although not statistically significant, results of this study indicated that $P$. cembra responded to soil warming with an increase and to soil cooling with a decline in stem radial growth, when compared to control trees with soil temperature left unmanipulated. Moreover, differences in stem growth with respect to soil temperature may also be attributed to varying soil nutrient contents with respect to micro topography (Anschlag et al., 2008).

Beside low temperatures, the termination of tree growth their upper distribution limit may also be attributed to a low availability of soil nutrients (Sveinbjörnsson et al., 1992) and hence also to an insufficient nutrient uptake (Susiluoto et al., 2010). Particularly total and available nitrogen (N), which is a key nutrient, is known to limit plant productivity in numerous terrestrial ecosystems (LeBauer and Treseder, 2008). This also holds for the treeline ecotone (Tranquillini, 1979) where low soil temperatures limit $\mathrm{N}$ mineralization and decomposition (Nadelhoffer et al., 1991; Rustad et al., 2001; Melillo et al., 2002). Yet, soil fertilization studies in boreal treelines indicated enhanced tree growth after soil fertilization (Weih, 2000; Weih and Karlsson, 2001; Susiluoto et al., 2010).

Beside the two abiotic factors, low temperature and low nutrient availability, root competition for nutrients may also have a noticeable influence on tree growth (Nilsson and Wardle, 2005; Matsushima and Chang, 2006; Elliott et al., 2015; Du et al., 2016). There are some data indicating that the absence of understory (i.e., the removal of below-ground competition) may enhance tree (Platt et al., 2004; Song et al., 2016) and seedling growth (Okano and Bert-Hane, 2015) in subalpine forests and the treeline ecotone, respectively. To our knowledge, however, the role of root competition between adult trees and understory vegetation in regulating tree growth at treeline in the Central European Alps received no attention.
Although the intra-annual stem radial increment of $P$. cembra has been studied intensively at the alpine treeline (Loris, 1981; Rossi et al., 2006, 2007; Gruber et al., 2009a,b), the responses of radial growth to soil warming, soil fertilization, and below ground competition, respectively, still awaits clarification for conifers at the alpine treeline. In this unique study, we investigated how soil temperature, $\mathrm{N}$ fertilization, and understory removal influences stem radial growth of $P$. cembra at treeline. Additionally, we also estimated root biomass, needle and foliar nutrient concentrations as well as specific leaf area. We hypothesized that: (1) soil warming, (2) understory removal, and (3) $\mathrm{N}$ fertilization will enhance radial growth of $P$. cembra at treeline in the Central Tyrolean Alps. Soil warming and understory removal was incited by root-zone roofing throughout three consecutive growing seasons, while continuously monitoring intra-annual changes in stem radius with electronic band dendrometers (Gruber et al., 2010; Oberhuber, 2017). In addition, some trees received a soil nitrogen fertilization. Findings are expected to contribute to an increased understanding of the importance of root competition and soil $\mathrm{N}$ fertilization on tree growth at treeline in the Central Austrian Alps, where mean annual air temperature increased by $0.50^{\circ} \mathrm{C}$ per decade, during the past 35 years (Wieser et al., 2016).

\section{MATERIALS AND METHODS}

\section{Study Site and Experimental Design}

The study was carried out in a south exposed P. cembra afforestation at treeline above Haggen near St. Sigmund in the Sellrain Valley, Tyrol, Austria ("Haggener Sonnberg," $47^{\circ} 12^{\prime} 42^{\prime \prime} \mathrm{N}, 11^{\circ} 05^{\prime} 04^{\prime \prime} \mathrm{E}, 2150 \mathrm{~m}$ a.s.l.). Slope angel and aspect were $25^{\circ}$ and SSW, respectively (Kronfuss, 1997). The long term mean annual temperature (1975-1994) at a nearby weather station at $1800 \mathrm{~m}$ a.s.l. (Kronfuss, 1997) was $3.2^{\circ} \mathrm{C}$ and the mean annual precipitation was $909 \mathrm{~mm}$. For the same period the growing season (May through September) had a mean air temperature of $8.5^{\circ} \mathrm{C}$ and a mean precipitation of $537 \mathrm{~mm}$. The soil at our study site is a podzolic cambisol (Neuwinger, 1972; World Base for soil Resources classification, FAO, 2008) which derived from gneisses and mica schist bedrock (Kronfuss and Havranek, 1999). The sandy loam subsoil was covered by a ca. $5 \mathrm{~cm}$ thick humus layer (Wieser et al., 2015). Hydraulic field capacity at $-0.033 \mathrm{MPa}$ (sensu Blume et al., 2010) of the top sub soil $(0-25 \mathrm{~cm})$ is $25 \%$ volume and the top soil is enriched by $8 \%$ of organic matter (Wieser et al., 2015).

The stand formed a sparsely open canopy permitting a dense understory of herbaceous species together with some dwarf shrubs. During the study period (2011-2014) the trees were $\approx 25$ years old, with a stem diameter at breast height of $7.1 \pm 1.2 \mathrm{~cm}$, and an average height of $3.4 \pm 0.4 \mathrm{~m}$. Trees selected for the experiment were separated at least by a distance of 3-5 m. In early summer 2011 we established 24 quadratic $16 \mathrm{~m}^{2}$ plots with one P. cembra tree in the center, resulting in six plots each of the four experimental groups: (1) nitrogen $(\mathrm{N})$ fertilization ( $\mathrm{N}$ treatment), (2) an increase in soil temperature (warming treatment), (3) elimination of understory vegetation (understory removal treatment), and (4) controls, for with soil 
temperature left un-manipulated, the understory vegetation was present (competition), and trees were not fertilized (control treatment). In order to facilitate the logistics of soil temperature and soil moisture monitoring (see below), three adjacent plots per treatment were assembled into a block.

The nitrogen plots were fertilized following the recommendations of Kilian and Müller (1994). The plots were fertilized twice, in spring 2012 and 2013, with $10 \mathrm{~g} \mathrm{~m}^{-2}$ calcium ammonium nitrate (NAC $27 \mathrm{~N}$; Borealis L.A.T., AT) containing $27 \%$ nitrogen with equal parts of $\mathrm{NO}_{3}-\mathrm{N}$ and $\mathrm{NH}_{4}$ and $12 \% \mathrm{CaO}$; the latter counteracting potential effects of $\mathrm{N}$ acidification. Soil warming was achieved by roofing the forest floor with a heat trapping $0.5-\mathrm{mm}$ thick transparent polyvinyl skin (Wieser et al., 2015). In the no understory plots, herbaceous species and dwarf shrubs were completely removed in July 2011. This condition was maintained by shading the forest floor with a non-transparent foil. The respective foils were fixed on frames $15 \mathrm{~cm}$ above ground. The sides were open for allowing air circulation. Surface and slope run-off of water was allowed to penetrate the soil during and after rainfall (in total $67 \%$ of precipitation; Neuwinger et al., 1988; Wieser et al., 2015). Soil warming and understory removal through shading operated from end July throughout October 2011, and continued during the snow-free periods (May-October) of 2012, 2013, and 2014.

As expected, understory removal through shading was accompanied by root-zone cooling. Additionally, there is also evidence that artificial soil cooling by roofing the forest floor may have negative effects on stem radial growth of $P$. cembra growing in the krummholz (crippled trees) limit at $2180 \mathrm{~m}$ a.s.l. on Mt. Patscherkofel south of Innsbruck, Austria (Gruber et al., 2010). Therefore, in order to discriminate between potential antagonistic effects of understory removal and soil cooling on radial growth, we also removed the understory in all the control and warmed plots in early April 2014 and covered the ground with a permeable weed fleece to avoid any re-growth of the understory vegetation throughout the entire growing season of 2014. Detailed information on potential understory competition with respect to treatment is given in Table 1.

\section{Environmental Measurements and Dendrometer Records}

Air temperature $\left(T_{\text {air }}\right)$ and relative humidity (CS215 Temperature and Relative Humidity Sensor), solar radiation (SP1110 Pyranometer Sensor), wind velocity (A100R Anemometer) and precipitation (ARG100 Rain Gauge, all sensors Campbell Scientific, Shepshed, United Kingdom)

TABLE 1 | Understory characteristics in the control, the warming, the understory removal, and the $\mathrm{N}$ fertilization treatment during the growing seasons 2012, 2013, and 2014.

\begin{tabular}{lccc}
\hline Treatment & $\mathbf{2 0 1 2}$ & $\mathbf{2 0 1 3}$ & $\mathbf{2 0 1 4}$ \\
\hline Control & Intact understory & Intact understory & No understory \\
Warming & Intact understory & Intact understory & No understory \\
Understory removal & No understory & No understory & No understory \\
N treatment & Intact understory & Intact understory &
\end{tabular}

were measured continuously at $2 \mathrm{~m}$ height at the study site. In order to examine differences in the seasonal course of soil temperature $\left(T_{\text {soil }}\right)$ and volumetric soil water content $(\theta)$ between control, warming, and understory removal blocks, six soil temperature probes (T 107 Temperature Probe, Campbell Scientific, Shepshed, United Kingdom) and two soil moisture sensors (EC 5 Soil Moisture Sensor, Decagon Devices Inc. Pullman, WA, United States) were installed in each block close to the trees used for dendrometer records. While $\theta$ was measured at $10 \mathrm{~cm}$ soil depth solely, $T_{\text {soil }}$ was measured at 5 , 10 , and $20 \mathrm{~cm}$ soil depth (two probes per depth and block). To evaluate a potential influence of forest-floor roofing on stem temperature $\left(T_{\text {stem }}\right)$, a T 107 Temperature Probe (Campbell Scientific, Shepshed, United Kingdom) was mounted at $50 \mathrm{~cm}$ stem height on the north facing side of all the trees in control, warmed and understory removal treatment, respectively. All the environmental data were recorded with two CR1000 data loggers (Campbell Scientific, Shepshed, United Kingdom) programmed to record 30-min averages of measurements taken every minute.

Intra-annual changes in stem radius of all the selected study trees were continually monitored using electronic band dendrometers with automatic temperature compensation (DC2, Ecomatik, Dachau, Germany) installed $0.5 \mathrm{~m}$ aboveground in early May 2011 to record intra-annual radial growth throughout the snow free periods (April-October) of 2012, 2013, and 2014. The measuring cable consisted of Invar-steel with a thermal expansion coefficient $<1.4 \times 10^{-6} \mathrm{~K}$. Dead outermost layers (periderm) of the bark were slightly removed to reduce the influence of hygroscopic swelling and shrinkage of the bark on dendrometer traces and to ensure close contact with the stem (cf. Gruber et al., 2009a,b; Oberhuber, 2017). Data were recorded with a CR1000 data logger (Campbell Scientific, Shepshed, United Kingdom) programmed to record 30-min averages of measurements taken every minute. Circumference variations derived from band dendrometers were transformed to radial variations, and daily stem radius variations were determined by calculating the difference between mean values of two consecutive days (“daily mean approach,” Deslauriers et al., 2007). As for dendrometers no unambiguous date of growth onset can be determined (Downes et al., 1999; Deslauriers et al., 2003; Gruber et al., 2009b), we defined the onset of radial growth as the date when radial increment permanently exceeded the initial value after snow melt in May. To separate daily patterns of water movement from irreversible expansion growth, we applied a Gompertz function for describing the long-term development of radial growth over an entire growing season according to Rossi et al. (2006):

$$
y=A * \exp [-\exp (\beta-\kappa t)]
$$

where $y$ is the cumulative sum of growth, $A$ is the upper asymptote of the total annual radial growth, $\beta$ is the $x$-axis placement parameter, $\kappa$ is the rate of change parameter, and $\mathrm{t}$ is the time computed in Julian days. The inflection point $\left(I_{\mathrm{p}}\right)$ corresponding to the maximum value of the radial growth rate was calculated as $I_{\mathrm{p}}=\beta / \kappa$ (Rossi et al., 2006). Finally, as dendrometer records are affected by stem water status, the end 

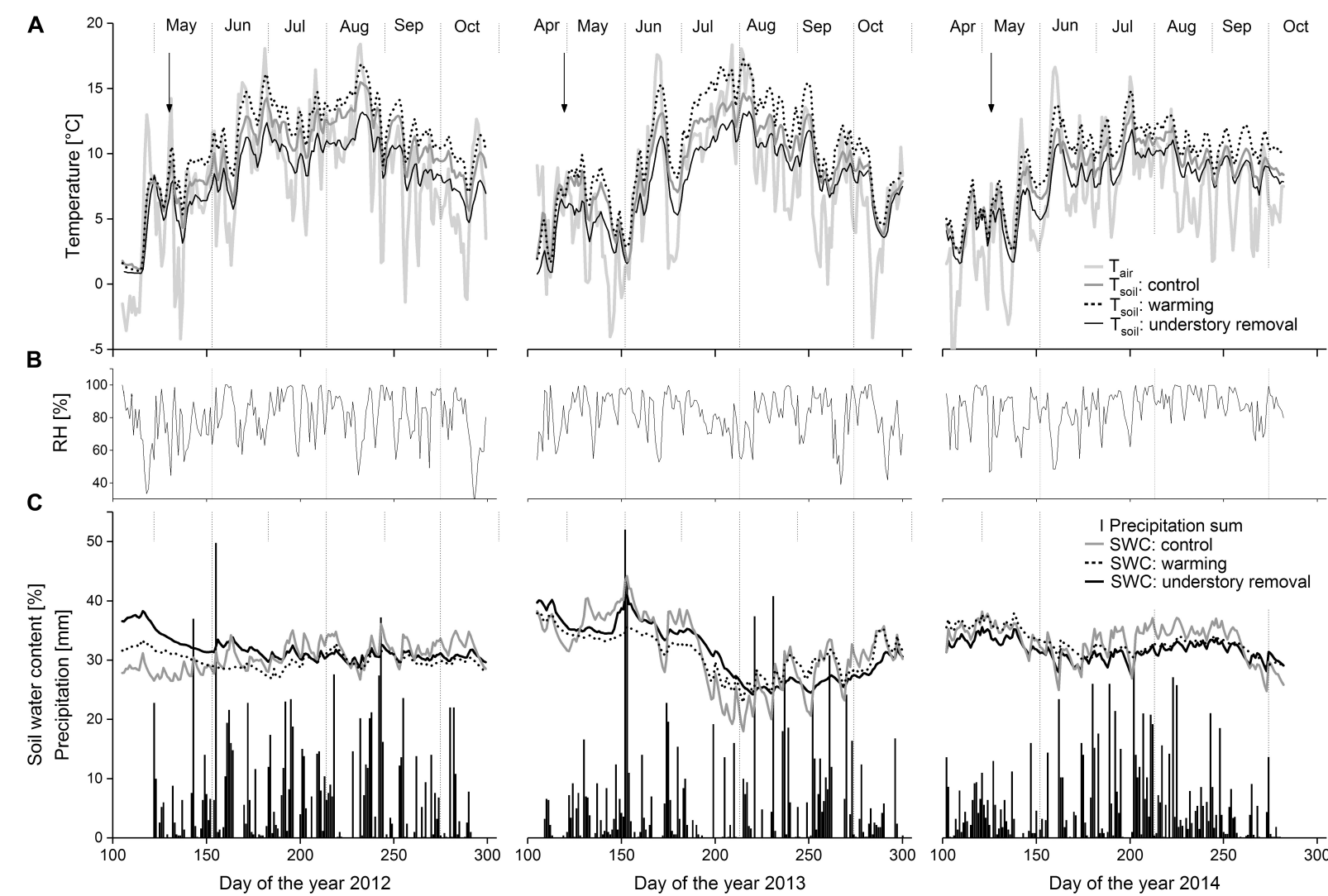

FIGURE 1 | (A) Seasonal course of daily mean air temperature and daily mean soil temperatures in $10 \mathrm{~cm}$ soil depth in control, warming and understory removal blocks. (B) Relative air humidity. (C) Daily sum of precipitation and daily mean soil water content in $10 \mathrm{~cm}$ soil depth in control, warming and understory removal blocks from April to October 2012, 2013, and 2014. Arrows indicate roof closure.

of stem radial growth was considered when $90 \%$ of $A$ given by the Gompertz function was reached (Gruber et al., 2009b).

\section{Additional Measurements}

Tree characteristics including specific leaf area (SLA), 100 needle dry weight, and foliar nutrient concentrations of all the study trees, as well as root biomass at the plot level were determined in late fall 2013 (November 18, 2013). SLA $\left(\mathrm{cm}^{2} \mathrm{~g}^{-1}\right)$ was calculated from measured needle dry weight and measured projected needle surface area. For nutrient analyses the needles were dried to constant weight at $60^{\circ} \mathrm{C}$, ground and stored dry before analysis. The concentrations of nitrogen, phosphor and potassium were estimated according to EPA $3052^{1}$. For assessing root biomass mass (including tree and understory vegetation roots) at the plot

${ }^{1}$ https://www.epa.gov/

TABLE 2 | Seasonal average soil temperature $\left(T_{\text {soil }}{ }^{\circ} \mathrm{C}\right)$ at 5,10 , and $20 \mathrm{~cm}$ soil depth and volumetric soil water content $(\theta)$ at $10 \mathrm{~cm}$ soil depth, in control, warmed and understory removal blocks for the periods May 1-September 30, 2012, 2013, and 2014.

\begin{tabular}{|c|c|c|c|c|c|}
\hline Year & Treatment & $T_{\text {soil }} 5 \mathrm{~cm}$ & $T_{\text {soil }} 10 \mathrm{~cm}$ & $T_{\text {soil }} 20 \mathrm{~cm}$ & $\theta 10 \mathrm{~cm}$ \\
\hline & Warming & $12.4 \pm 0.2^{b}$ & $11.9 \pm 0.2^{b}$ & $11.1 \pm 0.2^{b}$ & $30.0 \pm 0.1^{a}$ \\
\hline \multirow[t]{3}{*}{2013} & Control & $10.1 \pm 0.3^{a}$ & $9.8 \pm 0.3^{a}$ & $9.4 \pm 0.2^{\mathrm{a}}$ & $31.0 \pm 0.2^{a}$ \\
\hline & Warming & $12.1 \pm 0.3^{b}$ & $11.3 \pm 0.3^{b}$ & $10.5 \pm 0.3^{b}$ & $30.5 \pm 0.3^{a}$ \\
\hline & Understory removal & $8.6 \pm 0.3^{c}$ & $8.3 \pm 0.2^{c}$ & $7.9 \pm 0.2^{c}$ & $28.3 \pm 0.4^{a}$ \\
\hline & Understory removal & $8.4 \pm 0.2^{\mathrm{c}}$ & $8.1 \pm 0.2^{\mathrm{C}}$ & $7.8 \pm 0.2^{\mathrm{C}}$ & $31.6 \pm 0.1^{a}$ \\
\hline
\end{tabular}

Values are the mean $\pm S E$ of four sensors per treatment. Different letters indicate significant differences at $p<0.05$. 
level we sampled six soil cores (volume $125 \mathrm{~cm}^{3}$ ) per treatment in $0-10$ and in $10-20 \mathrm{~cm}$ soil depth, respectively. Roots were rinsed with tap water in a sieving cascade to remove all soil particles while minimizing the loss of fine roots. Subsequently, the roots were divided into fine (diameter $\leq 1 \mathrm{~mm}$ ) and coarse roots (diameter $>1 \mathrm{~mm}$ ) and dried to constant weight at $75^{\circ} \mathrm{C}$ before determining dry weight. Finally, increment cores $(5 \mathrm{~mm}$ in diameter) were taken at sensor height in fall 2014 for estimating radial increment in 2010, the year preceding the experiment.

\section{Data Analysis}

As daily mean $T_{\text {soil }}$ and $\theta$ values in the two control, the two warmed, and the two understory removal blocks, as well as $T_{\text {stem }}$ of all the trees under study did not differ significantly [all $P$-values $>0.1$; one-way analysis of variance (ANOVA)], we used repeated-measures ANOVA to test for differences in $T_{\text {soil }}, \theta$, and $T_{\text {stem }}$ between control, warmed, and understory removal blocks. Differences in the overall mean parameters of the Gompertz functions for modeling intra-annual radial growth (upper asymptote, inflection point, rate of change parameter, time when $90 \%$ of increment were produced) between the control, the warming, the understory removal, and the fertilization treatment during the growing seasons 2012, 2013, and 2014 were tested for significance using analysis of variance (ANOVA) and multiple comparison Tukey's HSD tests.

We used binary logistic regressions (logit models; SPSS for Windows) to determine the probability of radial growth being active at a given air and soil temperature. Values of daily radial increment where binary coded as: no increment (value 0) or increment (value 1) during the period May 1-September 30. The model was fitted for each tree, treatment and year with the respective temperature series; i.e., daily mean air and soil temperature in $10 \mathrm{~cm}$ soil depth. Temperature thresholds were calculated when the probability of radial increment was 0.5 (cf. Rossi et al., 2007). Fitting verification included $\chi^{2}$ of the likelihood ratio, Wald's $\chi^{2}$ for regression parameter and goodness of fit, and Hosmer-Lemeshow $\hat{C}$ for eventual lack of fit. Finally, thermal thresholds were averaged over the three snow free periods 2012, 2013, and 2014 and compared between treatments (control, warmed, understory removal $\approx$ cooling) using ANOVA.

ANOVA was also used for testing differences in SLA, needle area, needle mass, needle nutrient concentrations, and total fine root mass between treatments. A probability level of $P<0.05$ was considered as statistically significant and $P$-values $\geq 0.05$ and $<0.1$ as marginally significant. Statistical analyses were made with the IBM SPSS Statistics 21 (IBM, NY, United States).

\section{RESULTS}

\section{Environmental Conditions}

Growing season (May-September) mean $T_{\text {air }}$ (Figure 1) was $9.0^{\circ} \mathrm{C}$ in $2012,8.1^{\circ} \mathrm{C}$ in 2013 , and $7.3^{\circ} \mathrm{C}$ in 2014 . Daily mean relative humidity varied between $50 \%$ during cloudless warm days and close to $100 \%$ on overcast rainy days (Figure 1). Stem temperature at $50 \mathrm{~cm}$ stem height was not considerably altered by

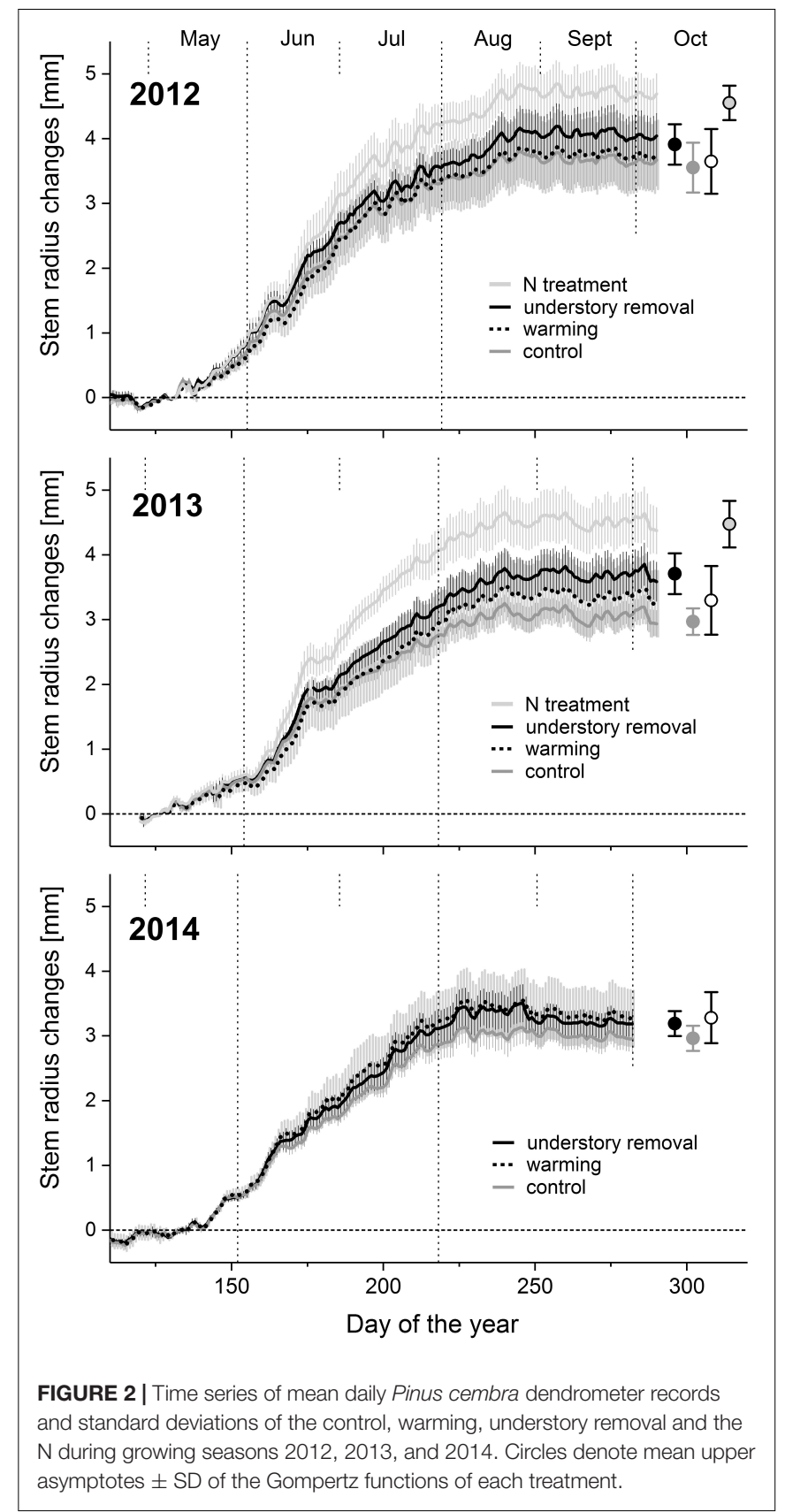

the experimental setup (data not shown; $P$-values from repeated measure analysis: $P=0.215, P=0.418$, and $P=0.390$ for 2012, 2013, and 2014, respectively).

Independent of treatment, $T_{\text {soil }}$ generally followed seasonal trends in $T_{\text {air }}$ (Figure 1). Warming caused $T_{\text {soil }}$ to average $+1.5 \pm 0.5,+1.3 \pm 0.2$, and $+1.0 \pm 0.2^{\circ} \mathrm{C}$ above the corresponding control levels at 5,10 , and $20 \mathrm{~cm}$ soil depth, respectively (all $P<0.05$; Table 2 ). In the understory removal blocks by contrast, shading caused $T_{\text {soil }}$ to be at average $-3.0 \pm 0.8,-2.6 \pm 0.5$, and $-2.4 \pm 0.4^{\circ} \mathrm{C}$ below the corresponding control levels at 5,10 , and $20 \mathrm{~cm}$ soil depth, respectively (all $P<0.05$; Table $\mathbf{1}$ ). 
Precipitation during the growing seasons 2012, 2013, and 2014 amounted 940, 806, and $785 \mathrm{~mm}$, respectively. Due to frequent precipitation over the entire growing seasons (Figure 1) soil water content $(\theta)$ in $10 \mathrm{~cm}$ soil varied between 44 and $19 \%$ vol. (Figure 1). Average $\theta$ over the growing seasons 2012, 2013, and 2014 did not differ significantly (all $P>0.64$ ) between control (30.8 $\pm 0.3 \%$ vol.), warmed (31.1 $\pm 1.6 \%$ vol.) and understory removal (shaded) blocks (30.1 $\pm 1.7 \%$ vol.), respectively (Table 2).

\section{Treatment Effects on Growth}

In 2010, the year preceding the experiment, annual radial stem increment did not differ significantly (all $P>0.45$ ) between the treatments and averaged $3.5 \pm 0.7,3.4 \pm 0.5$, $3.9 \pm 0.5$, and $3.8 \pm 0.7 \mathrm{~mm}$ in the control, the warming, the understory removal, and the fertilization treatment, respectively. The corresponding values for 2011 were $3.2 \pm 0.7,3.1 \pm 1.0$, $3.5 \pm 0.4$, and $3.4 \pm 0.6 \mathrm{~mm}$, respectively. Independent of treatment and year, radial growth started in the 2nd week of May (doy 128-133; Figure 2). Based on the calculated Gompertz functions, maximum daily radial growth peaked in June around summer solstice (doy 167-173) and radial growth ended in early August (doy 218-227), with no treatment effects (Table 3). Treatment, however, affected total annual stem radial increment (Table 3), which corresponds to the upper asymptote of the Gompertz function (Figure 2). Fertilization caused annual radial growth to increase significantly by 28 and $48 \%$ in 2012 and 2013, respectively, (both $P<0.004$ ) above the level of the control treatment (Figure 2 and Table 3). Understory removal caused radial growth to increase marginally significant on average by $11 \%(P=0.08)$ in 2012 , and significantly on average by $22 \%$ $(P=0.04)$ in 2013 above the level of control trees (Figure 2 and Table 3). However, it has to be noted that understory removal through shading was accompanied by significant cooling of the rooting-zone (cf. Figure $\mathbf{1}$ and Table 2 ). Warmed and control trees by contrast, resembled each other with respect to radial growth (Figure 2), in the absence of a warming effect on annual stem radial increment in 2012 and 2013 (Table 3). Removing the understory in 2014 in all the control and warmed plots also failed to find significant temperature effects (both $P>0.35$ ) on total annual stem radial increment between the control, the warming and the understory removal treatment (Table 3).

\section{Threshold Temperatures}

The calculated threshold temperatures at which radial growth had a 0.5 probability of being active were averaged over the three growing seasons 2012, 2013, and 2014. Irrespective of treatment, the mean air temperature at which radial growth of $P$. cembra was active in control, warmed and understory removal plots varied between 5.1 and $5.9^{\circ} \mathrm{C}$ (Table 4 ; all $P>0.05$ ). The mean soil temperatures at which there was a 0.5 probability of radial growth were in general higher than the air temperature thresholds, being $7.8 \pm 0.4,9.1 \pm 0.6$ and $6.0 \pm 0.6^{\circ} \mathrm{C}$ in the control, the warmed, and the understory removal treatment, respectively (Table 4; all $P<0.05)$.

\section{Specific Leaf Area, Foliar Nutrient Concentrations of the Study Trees and Plot-Level Fine Root Biomass}

Treatment did not influence SLA $(P=0.98)$. At the end of the growing season 2013 current-year needle SLA averaged $43.5 \pm 1.4 \mathrm{~cm}^{2} \mathrm{~g}^{-1}$ across all treatments. Current year 100needle surface area and the corresponding 100-needle dry weight, however, were significantly higher in the understory removal and fertilization treatment than in the warming and the control treatment (Figure 3). Treatment had no effect in foliar nutrient concentrations. Averaged across all the four treatments nitrogen, phosphor and potassium concentrations of current-year needles were $18.3 \pm 1.3,1.9 \pm 01$, and $5.7 \pm 0.4 \mathrm{mg} \mathrm{g}^{-1}$, respectively, at the end of the growing season 2013.

The impact of understory removal is also reflected at the plot level. After three growing seasons total fine-root biomass mass (including tree and understory vegetation roots) in $0-10 \mathrm{~cm}$ soil depth was significantly lower in understory removal plots as compared to control and warmed (both $P<0.05$ ) plots (Table 5). Although statistically not significant, total fine-root biomass mass in fertilized plots was considerably reduced when compared to warmed, and control plots, but considerably higher than in understory removal plots (Table 5). Treatment, however, had no effect on tree root biomass in $0-10 \mathrm{~cm}$ soil depth as well as on total fine-root biomass in the $10-20 \mathrm{~cm}$ soil layer (Table 5).

\section{DISCUSSION}

In this study, we tested the hypothesis that stem radial growth of $P$. cembra at treeline in the Central Tyrolean Alps is enhanced by soil warming, understory removal, as well as $\mathrm{N}$-fertilization. Our experimental approach was appropriate to manipulate $T_{\text {soil }}$, competition and $\mathrm{N}$ availability, enabling the clarification of radial growth in situ under a wide range of conditions. Although the roofing prevented $33 \%$ of growing season precipitation to reach the soil, treatment differences in daily mean $\theta$ between control, warmed and understory removal blocks stayed within the typical variation of at the study site (Neuwinger, 1972) which confirmed that the employed roofing system did not prevent any shortage in soil water availability (Figure $\mathbf{1}$ and Table 2). This is further corroborated by sap flow measurements, where roofing caused sap flow density of $P$. cembra to increase above the levels of control trees, whereas leaf level net $\mathrm{CO}_{2}$ uptake, conductance for water vapor, and water-use efficiency stayed unchanged (Wieser et al., 2015). Therefore, we assumed that our roofing induced $33 \%$ reduction of growing season precipitation reaching the soil did not considerably influence radial growth as a potential "side-effect" due to soil roofing.

After 3 years of treatment, our results indicate that soil warming had no considerable effect on radial growth, which allows hypothesis (1) to be rejected. Although understory removal through shading was accompanied by root-zone cooling (Figure 1 and Table 2), understory removal as well as soil $\mathrm{N}$-fertilization significantly increased radial growth, confirming hypothesis (2) and (3). Despite the fact that growing season 
TABLE 3 | Parameters of the Gompertz function (Mean \pm SD) for intra-annual radial growth of Pinus cembra trees selected for dendrometer records in 2012, 2013, and 2014.

\begin{tabular}{|c|c|c|c|c|c|}
\hline Year & Treatment & $I_{\mathrm{p}}(\mathrm{DOY})$ & $\kappa$ & $90 \%$ DOY & $A(\mathrm{~mm})$ \\
\hline \multirow[t]{4}{*}{2012} & Control & $167 \pm 0.3^{a}$ & $0.044 \pm 0.003^{a}$ & $218 \pm 3.5^{a}$ & $3.71 \pm 0.41^{a}$ \\
\hline & Warming & $168 \pm 1.9^{a}$ & $0.043 \pm 0.003^{a}$ & $221 \pm 5.0^{\mathrm{a}}$ & $3.80 \pm 0.54^{a}$ \\
\hline & Understory removal & $166 \pm 2.4^{a}$ & $0.041 \pm 0.005^{a}$ & $222 \pm 8.0^{a}$ & $4.11 \pm 0.37^{a *}$ \\
\hline & $\mathrm{N}$ treatment & $168 \pm 2.2^{a}$ & $0.043 \pm 0.003^{a}$ & $220 \pm 4.8^{a}$ & $4.74 \pm 0.31^{b}$ \\
\hline \multirow[t]{4}{*}{2013} & Control & $168 \pm 3.0^{\mathrm{a}}$ & $0.043 \pm 0.003^{a}$ & $221 \pm 5.6^{a}$ & $3.09 \pm 0.20^{a}$ \\
\hline & Warming & $173 \pm 3.6^{a}$ & $0.041 \pm 0.002^{a}$ & $227 \pm 3.9^{a}$ & $3.49 \pm 0.60^{a b}$ \\
\hline & Understory removal & $171 \pm 2.6^{a}$ & $0.041 \pm 0.003^{a}$ & $223 \pm 8.4^{a}$ & $3.83 \pm 0.34^{b}$ \\
\hline & $\mathrm{N}$ treatment & $171 \pm 2.6^{a}$ & $0.044 \pm 0.002^{a}$ & $222 \pm 3.8^{a}$ & $4.59 \pm 0.43^{c}$ \\
\hline \multirow[t]{3}{*}{2014} & Control & $167 \pm 1.3^{a}$ & $0.042 \pm 0.001^{a}$ & $220 \pm 1.7^{a}$ & $3.08 \pm 0.53^{a}$ \\
\hline & Warming & $167 \pm 2.6^{a}$ & $0.044 \pm 0.003^{a}$ & $219 \pm 6.0^{a}$ & $3.48 \pm 0.46^{a}$ \\
\hline & Understory removal & $169 \pm 2.5^{\mathrm{a}}$ & $0.040 \pm 0.003^{a}$ & $227 \pm 7.3^{a}$ & $3.54 \pm 0.45^{a}$ \\
\hline
\end{tabular}

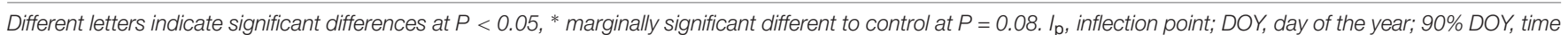
when $90 \%$ of increment was produced; $\kappa$, rate of change parameter, $A$ upper asymptote. Values are the mean $\pm S D$ of six trees per treatment.

stem radial growth of trees in the understory removal and the $\mathrm{N}$ addition treatment was significantly larger than in the control and warming treatment (Figure 2 and Table 3 ), we observed no considerable differences in the dynamics of tree growth (Figure 2).

Similar to our findings, Gruber et al. (2010) also failed to find a significant increase in radial growth of $P$. cembra in the kampfzone, i.e., the upper border line of the treeline ecotone (Körner, 2012), on Mt. Patscherkofel south of Innsbruck $(2.180 \mathrm{~m}$ a.s.l.) after 1 year of $0.5^{\circ} \mathrm{C}$ soil warming. An increase in soil temperature of $4^{\circ} \mathrm{C}$ and as a consequence a 1-week earlier snow melt also did not affect growth and cambial phenology of Picea mariana in a boreal forest in Canada (Lupi et al., 2012). Dao et al. (2015) also failed to find substantial effects on xylem phenology and cell production of mature black spruce after 6 years of soil warming by $4^{\circ} \mathrm{C}$ in a boreal forest. As in our study, 6 years of soil warming by $3.2^{\circ} \mathrm{C}$ in $10 \mathrm{~cm}$ soil depth at treeline in the Swiss Alps (2.180 $\mathrm{m}$ a.s.l.) also resulted in no considerable increase in the growth of $P$. uncinata, and Larix decidua during the first 2 years of the experiment (Hagedorn et al., 2010), while in the following 4 years slightly improved shoot growth persisted in P. uncinata, but diminished in L. decidua (Dawes et al., 2017). These observed differences in the response to soil warming may be attributed to differences in the rooting depth between pine and larch, because coarse roots of larch can penetrate into deeper soil layers when compared to pine (Kutschera and Lichtenegger, 2002), and thus may probably have not experienced the warming

TABLE 4 | Mean threshold temperatures corresponding with the 0.5-probability of active radial growth of Pinus cembra in the control, the warmed and the understory removal ( $\approx$ cooling) treatment estimated during the growing seasons 2012, 2013, and 2014.

\begin{tabular}{lcc}
\hline Treatment & $\boldsymbol{T}_{\text {air }}\left({ }^{\circ} \mathbf{C}\right)$ & $\boldsymbol{T}_{\text {soil }}\left({ }^{\circ} \mathbf{C}\right)$ \\
\hline Control & $5.9 \pm 0.6^{\mathrm{a}}$ & $7.8 \pm 0.4^{\mathrm{a}}$ \\
Warmed & $5.9 \pm 0.8^{\mathrm{a}}$ & $9.1 \pm 0.6^{\mathrm{b}}$ \\
Understory removal & $5.1 \pm 0.9^{\mathrm{a}}$ & $6.0 \pm 0.6^{\mathrm{c}}$ \\
\hline
\end{tabular}

Different letters indicate significant differences at $P<0.05$. treatment (Dawes et al., 2015). Strömgren and Linder (2002) reported an increase in stem production of boreal Picea abies trees in a 7-year study combining soil warming and nutrition.

The absence of significant growth stimulation due to soil warming in our study suggests that growth stimulation due to increasing soil temperatures may not be expected for P. cembra trees at treeline in the Central European Alps in the future. However, a potential effect of soil warming may occur under a longer period of experimentation (Dao et al., 2015), as there is evidence that P. cembra exhibits determinate shoot growth, in any year growth is primarily impelled by the bud formation occurring in the previous year (Tranquillini, 1979). Additionally, in alpine ecosystems, growth response to warming is mediated through a time lag by one or more years after initiation of warming (Danby and Hik, 2007; Hagedorn et al., 2010). Responses during the extraordinary warm year of 2003 support our result, as the growth of $P$. cembra at the treeline in the Austrian Alps was hardly affected by a $4^{\circ} \mathrm{C}$ warmer summer (Oberhuber et al., 2008).

As understory removal by shading was accompanied by a significant cooling of the rooting-zone (Figure 1 and Table 2), we were able to calculate threshold temperatures above which significant tree growth occurs (for a review see Körner, 2006). Körner and Paulsen (2004) found that a mean annual air temperature and $10 \mathrm{~cm}$ soil temperature threshold of $5.6-8.5^{\circ} \mathrm{C}$ and $6.4^{\circ} \mathrm{C}$, respectively, define the upper elevational limit of tree growth worldwide. For P. cembra in the Italian Alps, Rossi et al. (2007) estimated a daily threshold mean air temperature when radial growth was active of $5.8-8.6^{\circ} \mathrm{C}$. In our 3-year study period radial growth was active when mean air temperature was above $5.1-5.9^{\circ} \mathrm{C}$ (Table 4). Hence, our results support the existence of a comparable air temperature threshold for radial growth in $P$. cembra at the alpine treeline. Soil temperature thresholds by contrast differed significantly between treatments and ranged from $6.0^{\circ} \mathrm{C}$ in trees experiencing understory removal ( $\approx$ cooling) to $9.1^{\circ} \mathrm{C}$ in trees experiencing soil warming (Table 4), indicating that soil temperature is not the main limiting factor for radial growth for P. cembra at treeline (Rossi et al., 2007; Lupi et al., 2012). 

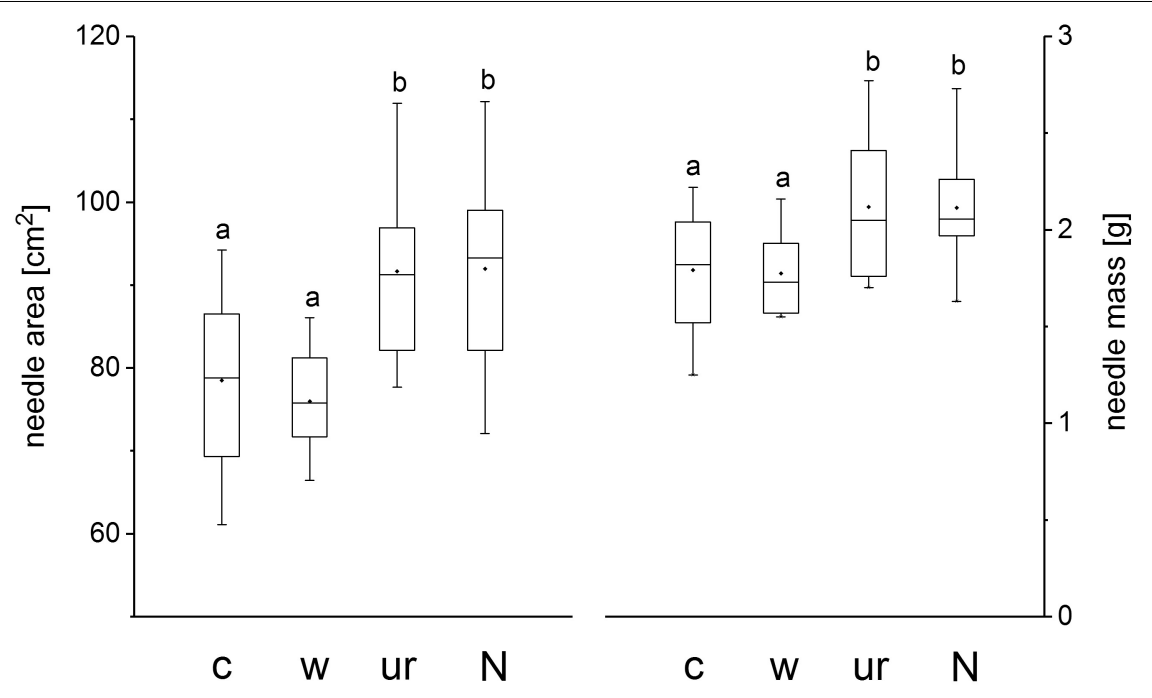

FIGURE 3 | Box plots showing the median, lower (25\%) and upper (75\%) quartile and minimum and maximum of 100 needle area and 100 needle mass of Pinus cembra trees in control (c), warmed (w), understory removal (ur) and $\mathrm{N}$ fertilized (N) plots at the end of the growing season 2013 . Different letters indicate significant differences at $P<0.05$.

Beside low temperatures, low soil nutrient availability may also affect tree growth at high altitude and latitude (Tranquillini, 1979; Jarvis and Linder, 2000; Rossi et al., 2011) because low soil temperatures limit mineralization, decomposition, and $\mathrm{N}$-cycling (Nadelhoffer et al., 1991; Rustad et al., 2001; Melillo et al., 2002). Thus, on the long term future climate warming may affect wood production, although no short term effect could be observed (Vaganov et al., 1999; Jarvis and Linder, 2000; Rustad et al., 2001; Rossi et al., 2007). Additionally, there is also evidence that fertilization effects may increase under conditions of experimental soil warming as shown for seedlings (Weih, 2000; Hoch, 2013) and mature forest trees (Rustad et al., 2001; Melillo et al., 2011; Lupi et al., 2012; but see Dao et al., 2015). In their soil heating study, Strömgren and Linder (2002) attributed the observed growth stimulation to an increase in $\mathrm{N}$ mineralization. The enhanced growth of P. uncinata at treeline in the Swiss Alps during the first 3 years of soil warming has also been attributed to a warming induced increase in soil $\mathrm{N}$ mineralization (Dawes et al., 2017). However, this was not investigated in our study.

As shown previously for boreal treeline sites (Sveinbjörnsson et al., 1992; Weih, 2000; Weih and Karlsson, 2001; Susiluoto et al., 2010), N-fertilization significantly increased radial growth of $P$. cembra at our study site (Figure 2 and Table 3). Similar to $\mathrm{N}$-fertilization, understory removal, and thus removal of root competition, also significantly enhanced stem growth of P. cembra (Figure 2 and Table 3). Removal of below-ground competition also enhanced tree (Platt et al., 2004; Song et al., 2016) and seedling growth (Okano and Bert-Hane, 2015) in subalpine forests and in the treeline ecotone, respectively. In addition, there is also evidence that the existence of understory can limit seedling and tree establishment above the current treeline (Smith et al., 2009; Batllori et al., 2010; Elliott, 2011; Grau et al., 2012). Assessment of long term changes in species interaction, however, are still a matter of debate (Matsushima and Chang, 2006; Liang et al., 2016; Camarero et al., 2017), and await clarification for the Central European Alps.

Nevertheless, beside enhanced stem growth, N-fertilization, as well as understory removal led to a significant increase in 100-needle surface area and 100-needle dry mass (Figure 3) which may be attributed to a considerable increase in $\mathrm{N}$ uptake, although needle $\mathrm{N}$ concentration did not vary between treatments. Because a greater needle size with equal $\mathrm{N}$ concentrations implies a higher amount of $\mathrm{N}$ stored in needles, $\mathrm{N}$ uptake seemed indeed to be a limiting factor at our study site as trees did profit from $\mathrm{N}$ addition and understory removal both, at the stem- and the canopy level. Moreover, at the plot level, understory removal significantly reduced total (=tree and understory vegetation) fine-root biomass in $0-10 \mathrm{~cm}$ soil depth,

TABLE 5 | Total (tree and understory) and tree fine-root biomass ( $\mathrm{g} \mathrm{dw} \mathrm{I}^{-1}$ soil); (Mean $\pm \mathrm{SD}$ ) in 0-10 $\mathrm{cm}$ and 10-20 cm soil depth in control (c), warmed (w), understory removal (ur) and $\mathrm{N}$ fertilized $(\mathrm{N})$ blocks at the end of the growing season 2013.

\begin{tabular}{|c|c|c|c|c|c|}
\hline Soil depth & Root biomass & c & $\mathbf{w}$ & ur & $\mathbf{N t}$ \\
\hline $0-10 \mathrm{~cm}$ & Tree and understory ${ }^{1}$ & $9.4 \pm 2.9^{a}$ & $9.8 \pm 2.0^{a}$ & $4.5 \pm 1.6^{b}$ & $7.6 \pm 1.4^{a b}$ \\
\hline $0-10 \mathrm{~cm}$ & Tree $^{2}$ & $1.0 \pm 0.9^{a}$ & $1.2 \pm 1.6^{\mathrm{a}}$ & $0.8 \pm 0.6^{a}$ & $0.7 \pm 0.7^{a}$ \\
\hline $10-20 \mathrm{~cm}$ & Tree and understory ${ }^{1}$ & $3.1 \pm 1.4^{\mathrm{a}}$ & $3.5 \pm 0.6^{a}$ & $3.0 \pm 1.1^{\mathrm{a}}$ & $3.1 \pm 0.7^{a}$ \\
\hline
\end{tabular}

${ }^{1}$ This study. ${ }^{2}$ Data from Rainer et al. (2015). Different letters indicate significant differences at $P<0.05$. 
while tree root biomass was hardly affected when compared to control plots (Table 5). Thus our findings suggest that at treeline in the Central Austrian Alps root competition for nutrients as well as low soil nutrient availability, rather than soil warming limits tree growth of $P$. cembra.

\section{CONCLUSION}

Results of this study on the effect of soil warming, $\mathrm{N}$ fertilization, and understory removal on stem radial growth of $P$. cembra at treeline clearly showed that warming failed to induce enhanced stem growth, which allowed hypothesis (1) to be rejected. Understory removal as well as soil $\mathrm{N}$-fertilization by contrast, significantly increased radial growth, confirming hypothesis (2) and (3). As hypothesis (1) was rejected, results of this study strongly suggest that beside low air temperatures, the termination of tree growth at cold-climate tree life boundaries may also be attributed to root competition for nutrients

\section{REFERENCES}

Anschlag, K., Broll, G., and Holtmeier, F.-K. (2008). Mountain birch seedlings in the treeline ecotone, subarctic Finland: variation in above- and below-ground growth depending on microtopography. Arctic Antarct. Alp. Res. 40, 609-616. doi: 10.1657/1523-0430(07-087)[ANSCHLAG]2.0.CO;2

Batllori, E., Camarero, J. J., and Gutierrez, E. (2010). Current regeneration patterns at the treeline in the Pyrenees indicate similar recruitment processes irrespective to the past disturbance regime. J. Biogeogr. 37, 1938-1950.

Blume, H. P., Brümmer, G. W., Horn, R., Kandeler, E., Kögl-Knabler, I., Kretzschmar, R., et al. (2010). Scheffer/Schachtchabel: Lehrbuch der Bodenkunde. Heidelberg: Spektrum Akademischer Verlag.

Brockmann-Jerosch, H. (1919). Baumgrenze und Klimacharakter. Pflanzengeographische Kommission der Schweizerischen Naturforschenden Gesellschaft. Beiträge zur Landesaufnahme 6. Zürich: Rascher und Cie.

Camarero, J. J., Linares, J. C., Garcia-Cervigon, A. I., Batllori, E., Martinez, I., and Gutierrez, E. (2017). Back to the future: the responses of alpine treelines to climate warming are constrained by the current ecotone structure. Ecosystems 20, 683-700. doi: 10.1007/s10021-016-0046-3

Danby, R. K., and Hik, D. S. (2007). Responses of white spruce (Picea glauca) to experimental warming at a subarctic alpine treeline. Glob. Change Biol. 13, 437-451. doi: 10.1186/s40064-015-0833-x

Däniker, A. (1923). Biologische Studien über Baum- und Waldgrenzen, insbesondere über die klimatischen Ursachen und deren Zusammenhänge. Vierteljahresschrift Naturforsch. Ges. Zürich 68, 1-102.

Dao, M. C. E., Rossi, R., Walsh, D., Morin, H., and Houle, D. (2015). A 6-yer-long manipulation with soil warming and canopy nitrogen additions does not affect xylem phenology and cell production of mature black spruce. Front. Plant Sci. 6:877. doi: 10.3389/fpls.2015.00877

Dawes, M. A., Philipson, C. D., Fonti, P., Bebi, P., Hättenschwiler, S., Hagedorn, F., et al. (2015). Soil warming and $\mathrm{CO}_{2}$ enrichment induce biomass shifts in alpüine treeline vegetation. Glob. Change Biol. 21, 2005-2021. doi: 10.1111/gcb. 12819

Dawes, M. A., Schleppi, P., Hättenschwiler, P., and Hagedorn, F. (2017). Soil warming opens the nitrogen cycle at the alpine treeline. Glob. Change Biol. 23, 421-434. doi: $10.1111 / \mathrm{gcb} .13365$

Deslauriers, A., Anfodillo, T., Rossi, S., and Carraro, V. (2007). Using simple causal modelling to understand how water and temperature affect daily stem radial variation in trees. Tree Physiol. 27, 1125-1136. doi: 10.1093/treephys/27. 8.1125

Deslauriers, A., Morin, H., and Begin, Y. (2003). Cellular phenology of annual ring formation of Abies balsamea in the Quebec boreal forest (Canada). Can. J. For. Res. 33, 190-200. doi: 10.1093/treephys/tpx082 between trees and understory vegetation (Nilsson and Wardle, 2005; Matsushima and Chang, 2006; Elliott et al., 2015; Du et al., 2016). Finally, the presented results underscore the importance of including both temperature manipulation and species interactions in future studies on tree growth within the treeline ecotone.

\section{AUTHOR CONTRIBUTIONS}

AG, WO, and GW conceived and designed the experiments and analyzed the data. AG performed the experiments. GW, wrote the manuscript. WO and AG provided editorial advice.

\section{FUNDING}

This work was supported by the Austrian Science Fund Project Nos. FWF P22836-B16 and FWF P22206-B16.

Downes, G., Beadle, C., and Worledge, D. (1999). Daily stem growth patterns in irrigated Eucalyptus globulus and E. nitens in relation to climate. Trees 14, 102-111. doi: 10.1007/PL00009752

Du, Z., Cai, X., Bao, W., Chen, H., Pan, H., Wang, X., et al. (2016). Short-term vs. long-term effects of understory removal on nitrogen and mobile carbohydrates in overstory trees. Forests 7:67. doi: 10.3390/f7030067

Elliott, G. P. (2011). Influences of 20th century warming at the upper treeline contingent on local-scale interactions: evidence from a latitudinal gradient in the Rocky Mountains, USA. Glob. Ecol. Biogeogr. 20, 46-57. doi: 10.1111/j.14668238.2010.00588.x

Elliott, K. J., Vose, J. M., Knoepp, J. D., Climton, B. D., and Kloeppel, B. D. (2015). Functional role of the herbaceous layer in Eastern Deciduous forest ecosystems. Ecosystems 18, 221-236. doi: 10.1007/s10021-0149825-x

FAO (2008). World Reference Base for Soil Resources. Rome: FAO.

Grau, O., Ninot, J. M., Blanco-Moreno, J. M., van Logtestijn, R. S. P., Cornelissen, J. H. C., and Callaghan, T. V. (2012). Shrub-tree interactions and environmental changes drive treeline dynamics in the Subarctic. Oikos 121, 1680-1690. doi: 10.1111/j.1600-0706.2011.20032.x

Gruber, A., Wieser, G., and Oberhuber, W. (2009a). Intra-annual dynamics of stem $\mathrm{CO}_{2}$ efflux in relation to cambial activity and xylem development in Pinus cembra. Tree Physiol. 29, 641-649. doi: 10.1093/treephys/ tpp001

Gruber, A., Wieser, G., and Oberhuber, W. (2010). Opinion paper: effects of simulated soil temperature on stem diameter increment of Pinus cembra at the alpine timberline: a new approach based on root zone roofing. Eur. J. For. Res. 129, 141-144. doi: 10.1007/s10342-0090305-3

Gruber, A., Zimmermann, J., Wieser, G., and Oberhuber, W. (2009b). Effects of climate variables on intra-annual stem radial increment in Pinus cembra (L.) along the alpine treeline ecotone. Ann. For. Sci. 66:503.

Hagedorn, F., Martin, M., Rixen, C., Rusch, S., Bebi, P., Zürcher, A., et al. (2010). Short-term responses of ecosystem carbon fluxes to experimental soil warming at the Swiss alpine treeline. Biogeochemistry 97, 7-19. doi: 10.1007/s10533-0099297-9

Hoch, G. (2013). Reciprocal root-shoot cooling and soil fertilization effects on the seasonal growth of two treeline conifer species. Plant Ecol. Divers. 6, 21-30. doi: 10.1080/17550874.2011.643324

Hoch, G., and Körner, C. (2003). The carbon charging of pines at the climatic treeline: a global comparison. Oecologia 135, 10-21. doi: 10.1007/s00442-0021154-7

Holtmeier, F.-K. (2003). Mountain timberlines. Ecology, Patchiness, and Dynamics. Advances in Global Change Research, Vol. 14. Dordrecht: Kluwer Academic Publishers. doi: 10.1007/978-94-015-1254-1 
Holtmeier, F.-K., and Broll, G. (2007). Treeline advance - driving processes and adverse factors. Landsc. Online 1, 1-33. doi: 10.3097/LO.200701

Jarvis, P., and Linder, S. D. (2000). Constraints to growth of boreal forests. Nature 405, 904-905. doi: 10.1038/35016154

Kilian, W., and Müller, F. (1994). Neue Wuchsgebietsgliederung -Folgen für Herkunftsbezeichnung forstlichen Vermehrungsgutes. Österreichische Forstzeitung 4, 13-15.

Körner, C. (1998). A re-asessment of high elevation treeline positions and their explanation. Oecologia 115, 445-459. doi: 10.1007/s004420050540

Körner, C. (2006). "Significance of temperature in plant life," in Plant Growth and Climate Change, eds J. I. L. Morison and M. D. Morecroft (Oxford: Blackwell Publishing Ltd), 48-69. doi: 10.1002/9780470988695.ch3

Körner, C. (2012). Alpine Treelines. Functional Ecology of the Global High Elevation Tree Limits. Basel: Springer. doi: 10.1007/978-3-0348-0396-0

Körner, C., and Hoch, G. (2006). A test of treeline theory on a montane permafrost island. Arctic Antarct. Alp. Res. 38, 113-119. doi: 10.1657/1523-0430(2006) 038[0113:ATOTTO]2.0.CO;2

Körner, C., and Paulsen, J. (2004). A world-wide study of high altitide treeline temperatures. J. Biogeogr. 31, 713-732. doi: 10.1111/j.1365-2699.2003. 01043.x

Kronfuss, H. (1997). Das Klima einer Hochlagenaufforstung in der subalpinen Höhenstufe - Haggen im Sellraintal bei St. Siegmund, Tirol (Periode 1975-1994). Vienna: Forstliche Bundesversuchsanstalt.

Kronfuss, H., and Havranek, W. M. (1999). Effects of elevation and wind on the growth of Pinus cembra L. In a subalpine afforestation. Phyton 39, 99-106.

Kutschera, L., and Lichtenegger, E. (2002). Wurzelatlas mitteleuropäischer Waldbäume und Sträucher. Graz: Leopold Stocker Verlag.

LeBauer, D. S., and Treseder, K. K. (2008). Nitrogen limitation of net primary productivity in terrestrial ecosystems is globally distributed. Ecology 89, 371-379. doi: 10.1890/06-2057.1

Liang, E., Wang, Y., Piao, S., Lu, X., Camarero, J. J., Zhu, H., et al. (2016). Species interactions slow warming-induced upward shifts of treelines on the Tibetan Plateau. Proc. Natl. Acad. Sci. U.S.A. 113, 4380-4385. doi: 10.1073/pnas. 1520582113

Loranger, H., Zotz, G., and Bader, M. Y. (2016). Early establishment of trees at the alpine treeline: idiosyncratic species responses to temperature-moisture interactions. AoB Plants 8:plw053. doi: 10.1093/aobpla/plw053

Loris, K. (1981). Dickenwachstum von Zirbe, Fichte und Lärche an der alpinen Waldgrenze/Patscherkofel. Ergebnisse der Dendrometermessungen 1976/79. Mitt. Forstl. Bundesver. 142, 417-441.

Lupi, C., Morin, H., Deslauries, A., and Rossi, S. (2012). Xylogenesis in black spruce: does soil temperature matter? Tree Physiol. 32, 74-82. doi: 10.1093/ treephys/tpr132

Matsushima, M., and Chang, S. X. (2006). Vector analysis of understory competition, $\mathrm{N}$ fertilization, and litter layer removal effects on white spruce growth and nutrition in a 13-year-old plantation. For. Ecol. Manage. 236, 332-341. doi: 10.1016/j.foreco.2006.09.018

Melillo, J. M., Steudler, P. A., Aber, J. D., Newkirk, K., Lux, H., Bowles, F. P., et al. (2002). Soil warming and carbon-cycle feedbacks to the climate system. Science 298, 2173-2176. doi: 10.1126/science. 1074153

Melillo, L. M., Butler, S., Johnson, J., Mohan, J., Steudler, P., Lux, H., et al. (2011). Soil warming, carbon-nitrogen interactions, and forest carbon budgets. Proc. Natl. Acad. Sci. U.S.A 108, 9508-9512. doi: 10.1073/pnas.1018189108

Nadelhoffer, J. K., Giblin, A. E., Shaver, G. R., and Laiúndre, J. A. (1991). Effects of temperature and substrate quality on element mineralization in six Arctic soils. Ecology 72, 242-253. doi: 10.2307/1938918

Neuwinger, I. (1972). Standortuntersuchungen am Sonnberg im Sellrainer Obertal, Tirol. Mitt. Forstl. Bundesvers. 96, 177-207.

Neuwinger, I., Wieser, G., Winklehner, W., and Heiss, G. (1988). Soil water investigations at a high-level afforestation area near Haggen in the Sellrain Valley, Tirol. Österreichische Wasserwirtschaft 40, 57-61.

Nilsson, M. C., and Wardle, D. A. (2005). Understory vegetation as a forest ecosystem driver: evidence from a northern Swedish boreal forest. Front. Ecol. Environ. 3:421-428. doi: 10.1890/1540-9295(2005)003[0421:UVAAFE]2. $0 . \mathrm{CO} ; 2$

Oberhuber, W. (2017). Soil water availability and evaporative demand affect seasonal growth dynamics and use of stored water in co-occurring saplings and mature conifers under drought. Trees 31, 67-478. doi: 10.1007/s00468-0161468-4

Oberhuber, W., Kofler, W., Pfeifer, K., Seeber, A, and Wieser, G. (2008). Long term changes in tree-ring-climate relationships at Mt. Patscherkofel (Tyrol, Austria) since the mid-1980s. Trees 22, 31-40. doi: 10.1007/s00468-0070166-7

Okano, K., and Bert-Hane, M. S. (2015). Warming and neighbor removal affect white spruce seedling growth differently above and below treeline. Springer Plus 4:79. doi: 10.1186/s40064-015-0833-x

Piper, F. I., Vinegla, B., Linares, J. C., Camarero, J. J., Cavieres, L. A., and Fajardo, A. (2016). Mediterranean and temperate treelines are controlled by different environmental drivers. J. Ecol. 104, 691-702. doi: 10.1111/1365-2745. 12555

Platt, K. H., Allen, R. B., Coomes, D. A., and Wiseer, S. K. (2004). Mountain beech seedling responses to removal of below-ground competition and fertiliser addition. N. Z. J. Ecol. 28, 289-293.

Rainer, G., Kuhnert, R., Unterholzer, M., Dresch, P., Gruber, A., and Peintner, U. (2015). Host-specialist dominated ectomycorrhizal communities of Pinus cembra are not affected by temperature manipulation. J. Fungi 1, 55-75. doi: 10.3390/jof 1010055

Rossi, S., Deslauries, A., Anfodillo, T., and Carraro, V. (2007). Evidence of threshold temperatures for xylogenesis in conifers at high altitudes. Oecologia 152, 1-12. doi: 10.1007/s00442-006-0625-7

Rossi, S., Deslauries, A., Anfodillo, T., Morin, H., Saracino, A., Motta, R., et al. (2006). Conifers in cold environments synchronyze maximum growth rate of tree-ring formation with day length. New Phytol. 170, 301-310. doi: 10.1111/j. 1469-8137.2006.01660.x

Rossi, S., Morin, H., and Deslauries, A. (2011). Multi-scale influence of snowmelt on xylogenesis of black spruce. Arctic Antarct. Alp. Res. 43, 457-467. doi: 10. 1657/1938-4246-43.3.457

Rustad, L. E., Campbell, J. L., Marion, G. M., Norby, R. J., Mitchell, M. J., Hartley, A. E., et al. (2001). A meta analysis of the response of soil respiration, net nitrogen mineralization, and aboveground plant growth to experimental ecosystem warming. Oecologia 126, 543-562. doi: 10.1007/s0044200 00544

Smith, W. K., Germino, M. J., Johnson, D. M., and Reinhardt, K. (2009). The altitude of alpine treeline: a bellwether of climate change. Bot. Rev. 75, 163-190. doi: 10.1007/s12229-009-9030-3

Song, H., Cheng, S., and Zhang, Y. (2016). The growth of two species of subalpine conifer saplings in response to soil warming and intercompetition in Mt. Gongga on the south-eastern fringe of the Qinghai-Tibetan plateau, China. World J. Eng. Technol. 4, 398-412. doi: 10.4236/wjet.2016. 43039

Strömgren, M., and Linder, S. (2002). Effects of nutrition and soil warming on stemwood production in a boreal Norway spruce stand. Glob. Ghange Biol. 8, 1194-1204. doi: 10.1046/j.1365-2486.2002.00546.x

Susiluoto, S., Hilasvuori, E., and Berninger, F. (2010). Testing the growth limitation hypothesis for subarctic Scots pine. J. Ecol. 98, 1186-1195. doi: 10.1111/j.13652745.2010.01684.x

Sveinbjörnsson, B. (2000). North American and European treelines. External forces and internal processes controlling position. AMBIO 29, 388-395. doi: 10.1579/ 0044-7447-29.7.388

Sveinbjörnsson, B., Nordell, O., and Kauhanen, H. (1992). Nutrient relations of mountain birch growth at and below the elevational treeline in Swedish Lapland. Functional Ecology 6, 213-220. doi: 10.2307/23 89757

Tranquillini, W. (1979). Physiological Ecology of the Alpine Timberline. Tree Existence in High Altitudes with Special Reference to the European Alps. Berlin: Springer. doi: 10.1007/978-3-642-67107-4

Vaganov, E. A., Hughes, M. K., Kirdyanov, A. V., Schweingruber, F. H., and Silkin, P. P. (1999). Influence of snowfall and melting time on tree growth in subarctic Eurasia. Nature 400, 149-151. doi: 10.1038/22087

Walther, G.-R., Beißner, S., and Pott, R. (2005). "Climate change and high mountain vegetation shifts," in Mountain ecosystems. Studies in Treeline Ecology, eds G. Broll and B. Keplin (Berlin: Springer), 77-95.

Wardle, P. (1974). "Alpine timberlines," in Arctic and Alpine Environments, eds J. D. Ives and R. Barry (London: Methuen Publishing), 371-402. 
Weih, M. (2000). Delayed growth response of mountain birch seedlings to a decrease in fertilization and temperature. Funct. Ecol. 14, 566-572. doi: 10.1046/ j.1365-2435.2000.t01-1-00452.x

Weih, M., and Karlsson, P. S. (2001). Growth response of mountain birch to air and soil temperature: Is increasing leaf-nitrogen content an acclimation to lower air temperature? New Phytol. 150, 147-155. doi: 10.1046/j.1469-8137.2001. 00078.x

Wieser, G., Grams, T. E. E., Matyssek, R., Oberhuber, W., and Gruber, A. (2015). Soil warming increased whole-tree water use of Pinus cembra at the treeline in the Central Tyrolean Alps. Tree Physiol. 35, 279-288. doi: 10.1093/treephys/ tvp009

Wieser, G., Matyssek, R., Luzian, R., Zwerger, P., Pindur, P., Oberhuber, W., et al. (2009). Effects of atmospheric and climate change at the timberline of the Central European Alps. Ann. For. Sci. 66:402. doi: 10.1051/forest/2009023
Wieser, G., and Tausz, M. (2007). Trees at Their Uppert Limiz. Treelife Limitation at the Alpine Timberline. Dordrecht: Springer.

Conflict of Interest Statement: The authors declare that the research was conducted in the absence of any commercial or financial relationships that could be construed as a potential conflict of interest.

Copyright (C) 2018 Gruber, Oberhuber and Wieser. This is an open-access article distributed under the terms of the Creative Commons Attribution License (CC BY). The use, distribution or reproduction in other forums is permitted, provided the original author(s) and the copyright owner are credited and that the original publication in this journal is cited, in accordance with accepted academic practice. No use, distribution or reproduction is permitted which does not comply with these terms. 